\title{
Factors affecting the digestibility of nutrients
}

\author{
By J. M. McNab, Agricultural Research Council's Poultry Research Centre, King's \\ Buildings, West Mains Road, Edinburgh EH9 $3 \mathcal{F S}$, Scotland
}

In studies with poultry a standard way to evaluate diets is by measurement of their digestibility.

To determine what factors are likely to affect digestibility it is essential to know what happens to the food after it is eaten and how it is assimilated by the bird. A deeper understanding of the factors governing the digestion and absorption of carbohydrates, proteins and fats could lead to significant improvements in current feeding practices.

\section{Carbohydrates}

Unless enzymes are present for the hydrolysis of dietary polysaccharides it is unlikely that they will be digestible. The principal carbohydrate component in poultry diets is the plant reserve polysaccharide, starch, the digestion of which is started by salivary amylase and is continued in the crop. Bolton $(1962,1965)$ has shown the extensive hydrolysis of starch in the crop and its further degradation to lactic acid, acetic acid and ethanol. Ivorec-Szylit, Mercier, Raibaud \& Calet (1965) and Ivorec-Szylit (197I) proposed that the amylases of the endogenous microflora as well as those of salivary origin contributed to the digestion of starch in the crop. Dietary factors also influence starch hydrolysis; Ivorec-Szylit et al. (1965) found the rate of breakdown of dietary starch to be inversely proportional to the amount of free glucose. Mercier, Ivorec-Szylit, Guilbot \& Calet (1965) have shown that steampelleting made starch six times more accessible to attack by amylases. Recently Pritchard (1972a) has shown that sucrose was hydrolysed more rapidly in food which had been in the crop than in uneaten food and interpreted this to mean that, in the absence of bacteria, invertase or $\alpha$-glucosidase activity was being contributed by the bird. Enzymes of plant origin present in the food could also affect degradation in the crop. The quantitative significance of starch breakdown in the crop is still in doubt. Although Pritchard (1972b) states that up to $25 \%$ of dietary starch can be digested in the crop, the small intestine is still considered the main site of starch digestion and absorption.

Carbohydrates which escape digestion in the small intestine are potential substrates for the microflora of the large intestine. Thornburn \& Willcox (1965a,b) found that the dry-matter digestibility of four foods was reduced by caecectomy. Although the digestibility of cellulose was variable it was always reduced after removal of the caecums; digestibility of the hemicellulose fraction seemed independent of the 
microflora, but increased as the birds aged. Vohra \& Kratzer (1964) and Kratzer, Rajaguru \& Vohra ( 1967 ) attributed poor growth of chicks given low levels of gums to the poor digestibility of these carbohydrates.

\section{Proteins}

Inhibition of the proteolytic enzymes results in a marked reduction in the digestibility of dietary protein. Nesheim \& Carpenter (1967) suggested that proteins not digested in the small intestine enter the caecums where they undergo fermentation. Experimenting with fish meal of recognized poor quality, they showed that digestibility was higher in normal than in caecectomized birds. Payne, Combs, Kifer \& Snyder (1968), Salter \& Coates (1971) and Carpenter (1973) have supported the view that the microflora of the large intestine affects protein digestibility, particularly when the protein is poor in quality. Nitsan \& Alumot (1963) also reported that when raw soya beans were fed to young chicks, the digestibility of the protein was greatly reduced by caecectomy. However, experiments by Payne, Kifer, Snyder \& Combs (1971) with caecectomized birds and by Salter, Coates \& Hewitt (1974) with germfree chicks indicate that if microbial activity does increase digestibility, it is too small to be of much biological importance.

\section{Fats}

The digestion and absorption of fats has been well documented, excellent accounts having been given recently by Scott, Nesheim \& Young (1969), Pritchard (1972b), Annison (1974) and Fuller (1975). The factors which influence the digestibility of fats are also well-defined and can be summarized as follows: ( 1 ) the chain length of the fatty acid; (2) the degree of unsaturation; (3) the presence or absence of ester linkages; (4) the specific arrangement of the saturated and unsaturated fatty acids on the glycerol moiety of the triglyceride; (5) the age of the bird; (6) the ratio of saturated : unsaturated fatty acids; (7) the intestinal microflora; (8) the composition of the diet; (9) the amount and type of the triglycerides in the dietary fat.

Most work has been carried out with chickens but recently Whitehead \& Fisher (1975) have shown that turkey poults digest fat in a manner similar to chickens and that fat digestibility is affected by the same factors.

\section{Effect of food processing}

Many potential dietary ingredients contain compounds which have a deleterious effect on the performance of poultry, and recognition of this has led to a very rapid increase in food processing. Methods of processing can be divided into: (a) cold processes in which heat is not applied directly, e.g. storage, cracking, rolling, grinding, granulating, moistening, germinating and enzyme supplementation; and (b) hot processes such as steam-pelleting, autoclaving, extruding, popping, toasting, micronizing and cooking.

Storage. Most foodstuffs have to undergo some period of storage before feeding, and changes can take place which alter the digestibility characteristics of the components. 
For example, Opstvedt (1974) has reported that oxidation during storage of unstabilized fish meal can reduce its digestible energy value by up to $20 \%$. Fish meal rich in polyenoic fatty acids showed the greatest reduction. Although the deterioration process is not completely understood, it is attributed to the polymerization of the fatty acids and the formation of condensation products with proteins, thereby causing a reduction in the digestibility of both. Although numerous model studies have shown that protein digestibility can be lowered as a result of autoxidizing lipids, opinion is still divided as to the mechanism which interferes with digestibility (Njaa, Utne \& Braekkan, 1966). Damage to individual amino acids has been implicated, and the digestibility of methionine was lowered by $60 \%$ in oxidized anchovy meal (Bürke \& Maddy, I966) and by $16 \%$ in oxidized herring meal (Opstvedt, 1974).

Grinding. Current practices in the manufacture of complete diets make it essential that the component foodstuffs are ground to a meal before compounding and it has been suggested, particularly with cereals, that grinding improves the digestibility. For example, Fritz (1935) reported that grinding maize improved the digestibility of the organic matter. This improvement was attributed to an increase in the digestibility of the fat fraction. Mechanical rupture of the starch granules (Jones, 1940) has been suggested as a way of improving nutritive value of cereals, although increasing cereal starch digestibility hardly seems possible in view of the very high values reported for the untreated foodstuff (Vogt \& Stute, 1971). There is therefore little evidence to substantiate the view that milling improves the digestibility of poultry food, although ground barley appears to have a higher metabolizable energy (ME) value than the whole cereal (McIntosh, Slinger, Sibbald \& Ashton, 1962).

Granulation. Bolton (1960) and Curda, Snopkova, Muzik \& Cadkova (1963) were unable to show any alteration in dietary digestibility by granulation. Hussar \& Robblee (1962) observed no change in ME values after granulating diets containing maize, and similar results were obtained by McIntosh et al. (1962) with wheat. The effect of pelleting and granulation has been the subject of an exhaustive review by Calet (1965) who concluded that, although granulation of a diet is advantageous for poultry in terms of food conversion efficiency, the improvement could not be attributed to any increase in digestibility.

In a very illuminating paper by Saunders, Walker \& Kohler (1969) the increased nutritive value of wheat by-products after pelleting the diets was attributed to the rupture of the cell walls, which improves the digestibility of the contents of the aleurone cells. It was shown directly that the percentage of empty aleurone cells increased after the diets had been pelleted, an increase which corresponded to an improvement in the digestibility of the bran. The faecal protein level decreased proportionally as the number of empty cells increased, and the highest protein digestibility was always found in those diets which had been pelleted. It was claimed that the mechanical rupture of this cell wall material had allowed the digestive enzymes greater access to the cellular contents. Since heating alone produced no alteration, the improvement was associated with the pelleting stage of the process, 
although steam may soften the cell walls. It was also reported that regrinding of wheat shorts three times significantly increased the digestibility of their protein. This improvement was also attributed to the rupture of the aleurone cells by the shear forces. Since the aleurone fraction of bran contains $90 \%$ of the protein, $94 \%$ of the fat, almost all the B-vitamins and $60 \%$ of the minerals it seems probable that increases in the digestibility of the fats, vitamins and minerals will occur also. Pelleting has been reported to improve the digestibility of fat (Sell \& Thompson, 1965) and of phosphorus (Summers, Slinger \& Cisneros, 1967), although hydrolysis of phytates during steaming may have caused the latter improvement. In this context it is of interest that addition of dietary grit has been reported to affect digestibility (e.g. McIntosh et al. 1962). The shear created by the grit in the gizzard may be sufficient to rupture the aleurone cells and increase digestibility of their contents.

Water treatment. The digestibility coefficients of Western-grown barley have been shown to be improved by water treatment (Leong, Jensen \& McGinnis, 1962; Potter, Stutz \& Matterson, 1965). Leong et al. (1962) found that the addition of water to ground barley, mixing, drying at $70^{\circ}$ and grinding before incorporation into diets increased the ME value of Western pearled barley and regular barley by 26.1 and $24.6 \%$ respectively. The improvement was attributed in part to increased digestibility of the barley. Potter et al. (1965), in similar experiments, showed that the digestibility of the protein, fat and nitrogen-free-extract fractions were $0.45,0$ and 0.75 respectively for barley and $0.84,0.84$ and 0.78 for water-treated barley. Improvement of other poultry foods has also been reported after water treatment, although the explanation offered was not always an improvement in digestibility coefficients (Lepkovsky \& Furuta, 1960; Vohra, 1972).

Germination. Germination is known to result in an improvement in the nutritive value of various seed proteins, e.g. soya bean (Everson, Steenbock, Cederquist \& Parsons, 1944), although the factors affecting the improvement do not appear to have been studied extensively, particularly with the chicken. It is known that sprouted wheat can be fed to chicks safely (Falen \& Petersen, r969) and the nutritive value of maize and wheat, but not of barley, is improved by germination (Adams \& Naber, 1969).

Enzyme supplementation. The supplementation of poultry diets with various enzymes to improve the digestibility of certain compounds has been advocated and practised for many years. Barley-based diets have probably been the most intensively investigated because the low digestibilities reported for the nutrients in barley (Jakobsen, Gertov \& Nielsen, 1960; Vogt \& Stute, 197 I Petersen, 1972) are likely to offer most scope for improvement. Despite much effort being expended on the response of diets containing barley to enzyme supplementation (Jensen, Fry, Allred \& McGinnis, 1957; Arscott, McCluskey \& Parker, 1958; Fry, Allred, Jensen \& McGinnis, 1958; Rose \& Arscott, 1962; Burnett, I962, 1966), the dietary factors affected have not been conclusively defined. The response depends on the area where the barley is grown (Willingham, Leong, Jensen \& McGinnis, 1960), is more pronounced for young chicks than for older birds (Berg, 1961; Petersen \& Sauter, 
1968) and depends on the enzyme added (Petersen \& Sauter, 1968). An increase of $23.8 \%$ in the ME value of pearled barley and $14.5 \%$ in that of regular barley after the addition of a fungal enzyme to young chick diets was attributed, at least in part, to increased digestibility of the barley (Leong et al. 1962). A similar increase of $18.0 \%$ in the ME value of barley after addition of fungal enzyme was attributed to an increase in the digestibility of the crude protein, fat and carbohydrate components from 0.45 to 0.75 , 0 to 0.76 and 0.75 to 0.81 respectively (Potter et al. 1965). Neudoerffer \& Smith (1969) and Saunders, Conner, Edwards \& Kohler (1972) have shown that the digestibility of protein and carbohydrates in wheat bran is increased by treatment with cellulolytic enzymes following wet heating.

Heat treatment. Osborne \& Mendel (1917) first recorded that the nutritive value of certain protein-rich foodstuffs was improved by heat treatment and this has led to the recognition of the existence of many dietary compounds deleterious to animals. Several classes of antinutritive factors have been discovered and many foodstuffs have been found to contain one or more of them (Liener, 1969, 1973). Despite the research effort expended on investigating the mechanism of action of these factors, the precise mechanisms are seldom completely known. Decreased digestibility of the dietary protein, increased loss of endogenous protein and impairment of absorption of the nutrients in the ingesta have all been proposed as explanations of the harmful effects. It has been concluded that the principal effect is caused by interference with the pancreatic enzymes, trypsin and chymotrypsin, leading to reduced digestibility of the protein. With chicks the digestibility ratios of the amino acids in soyabean proteins varied from 0.569 to 0.916 in the absence of inhibitors whereas in their presence they varied from 0.494 to 0.830 (de Muelenaere, 1964). The factors in heat treatment influencing the digestibility of protein are the temperature applied, the time of exposure and the presence or absence of moisture. Inhibitors of proteolytic enzymes have been identified in many foodstuffs commonly fed to poultry, although those present in the soya bean are of most commercial significance. Other antinutritional factors which are known to affect digestibility of dietary components are haemagglutinins, amylase inhibitors, tannins, gossypol, phytates, goitrogens and saponins. Recent reviews dealing with such factors are available (Couch \& Hooper, 1972; Liener, 1973, 1974, 1975).

Preoccupation with attempts to correlate the beneficial effects of heat treatment with antinutritional factors has tended to obscure the favourable effects that heat could have on the digestibility of the protein and carbohydrate fractions of many foods. Structural changes in the carbohydrate and protein constituents induced by heat may well make them more susceptible to enzymic attack after ingestion. For example, micronization has been shown to increase the available carbohydrate content of field beans by $23.6 \%$ and the apparent dry-matter digestibility of chick diets containing beans by $8.0 \%$ (McNab \& Wilson, 1974). The heat provided by the process of steam-pelleting is recognized as improving the quality of diets for poultry (e.g. Bayley, Summers \& Slinger, 1968), although the characteristics affected are not always identifiable. Steam-pelleting can do one of three things likely to improve the value of a diet: ( 1 ) inactivate thermolabile toxic compounds; (2) increase the density 
of the diet, with a resultant increase in food intake; (3) change chemically the constituents of the dietary ingredients, e.g. cooking has long been considered to exert a beneficial effect on the digestibility of starches and evidence has been accumulated to indicate that the in vitro starch digestibility of barley, maize and sorghum can be increased by heat treatment (Mercier, 1971).

Heat has long been recognized as a factor lowering the nutritive value of many foodstuffs, particularly those rich in proteins and containing reducing groups. Amino acids in proteins with free amino groups are very susceptible to heat damage. Known as the Maillard or browning reaction, it is responsible for a decrease in the biological value of proteins, principally because of a decrease in the digestibility of lysine; tryptophan, histidine and arginine can also be affected. Although the chemistry of the Maillard reaction is not completely understood (Finot, r973) it is known to be accelerated by heat. Heat can also encourage other deleterious reactions, some of which result in new linkages both within and between peptide chains (Bjarnason \& Carpenter, 1970; Mauron, 1970; Ford, 1973). These new bonds are considered resistant to attack by the proteolytic enzymes and the digestibility of the adjacent peptide bonds may also be impaired. Several amino acids are exceedingly sensitive to heat, and methionine and cystine can disintegrate. Protein-rich foodstuffs do, however, differ in their susceptibility to heat. For instance the digestibility of blood meal is low and this is attributed to its particularly high sensitivity to heat, yet hydrolysed feathers and hair, both of which have been subjected to severe treatment, appear to be highly digestible by the chick (Doty, 1973).

Many factors influence the digestibility of the components of a diet and the research effort expended has led to a better understanding of the mechanisms involved. This has undoubtedly resulted in lower feeding costs, but to meet the need for food by an ever-expanding population there is scope for further studies on processing in order to maximize diet quality.

\section{REFERENCES}

Adams, O. L. \& Naber, E. C. (1969). Poult. Sci. 48,853.

Annison, E. F. (1974). In Energy Requirements of Poultry, p. 135 [T. R. Morris and B. M. Freeman, editors]. Edinburgh: Longman Group Ltd.

Arscott, G. H., McCluskey, W. H. \& Parker, J. E. (1958). Poult. Sci. 37, I 7 .

Bayley, H. S., Summers, J. D. \& Slinger, S. J. (1968). Poult. Sci. 47, 931.

Berg, L. R. (196r). Poult. Sci. 40, 34.

Bjarnason, J. \& Carpenter, K. J. (1970). Br. F. Nutr. 24, 313.

Bolton, W. (1960). Y. agric. Sci., Camb. 55, $14 \mathrm{I}$.

Bolton, W. (1962). Proc. Nutr. Soc. 2r, xxiv.

Bolton, W. (1965). Br. Poult. Sci. 6, 97.

Bürke, R. P. \& Maddy, K. H. (1966). Kraftfutter 49, 66.

Burnett, G. S. (1962). Br. Poult. Sci. 3, 89.

Burnett, G. S. (1966). Br. Poult. Sci. 7, 55.

Calet, C. (1965). Wld's Poult. Sci. F. 21, 23.

Carpenter, K. J. (1973). In Proteins in Human Nutrition, p. 343 [J. W. G. Porter and B. A. Rolls, editors]. London: Academic Press.

Couch, J. R. \& Hooper, F. G. (1972). In Never Methods of Nutritional Biochemistry, vol. 5, p. 183 [A. A. Albanese, editor]. London: Academic Press.

Curda, K., Snopkova, Z., Muzik, R. \& Cadkova, E. (1963). Sb. đsl. Akad. zeméd. Véd, Zivođišna výroba 36,681 .

de Muelenaere, H. J. H. (1964). J. Nutr. 82, r 97. 
Doty, D. M. (1973). Alternative Sources of Protein for Animal Production, p. 6r. Washington, DC: National Academy of Sciences.

Everson, G. J., Steenbock, H., Cederquist, D. C. \& Parsons, H. T. (1944). J. Nutr. $27,225$.

Falen, L. F. \& Petersen, C. F. (1969). Poult. Sci. 48, 1772.

Finot, P. A. (1973). In Proteins in Human Nutrition, p. $50 \mathrm{I}$ [J. W. G. Porter and B. A. Rolls, editors]. London: Academic Press.

Ford, J. E. (1973). In Proteins in Human Nutrition, p. 515 [J. W. G. Porter and B. A. Rolls, editors]. London: Academic Press.

Fritz, J. C. (1935). Poult. Sci. 14, 267.

Fry, R. E., Allred, J. B., Jensen, L. S. \& McGinnis J. (1958). Poult. Sci. 37, 372.

Fuller, H. L. (1975). In Animal Feeds of Tropical and Sub-tropical Origin. London: Tropical Products Institute.

Hussar, N. \& Robblee, A. R. (1962). Poult. Sci. 41, 1498.

Ivorec-Szylit, O. (1971), C. r. hebd. Séanc. Acad. Sci., Paris 272, 2225.

Ivorec-Szylit, O., Mercier, C., Raibaud, P. \& Calet, C. (1965). C. r. hebd. Seanc. Acad. Sci., Paris 261, 3201.

Jakobsen, P. E., Gertov, K. \& Nielsen, S. H. (1960). Beretn. Forsegslab. no. 322.

Jensen, L. S., Fry, R. E., Allred, J. B. \& McGinnis, J. (1957). Poult. Sci. 36, 919.

Jones, C. R. (1940). Cereal Chem. 17, 133.

Kratzer, F. H., Rajaguru, R. W. A. S. B. \& Vohra, P. (1967). Poult. Sci. 46, 1489.

Leong, K. C., Jensen, L. S. \& McGinnis, J. (1962). Poult. Sci. 41, 36.

Lepkovsky, S. \& Furuta, F. (1960). Poult. Sci. 39, 370.

Liener, I. E. (editor) (1969). Toxic Constituents of Plant Foodstuffs. New York and London: Academic Press.

Liener, I. E. (1973). In Proteins in Human Nutrition, p. 481 [J. W. G. Porter and B. A. Rolls, editors]. New York and London: Academic Press.

Liener, I. E. (1974). $\mathcal{Y}$. agric. Fd Chem. 22, I 7.

Liener, I. E. (1975). In Animal Feeds of Tropical and Sub-tropical Origin. London: Tropical Products Institute.

McIntosh, J. I., Slinger, S. J., Sibbald, I. R. \& Ashton, G. C. (1962). Poult. Sci. 4r, 445.

McNab, J. M. \& Wilson, B. J. (1974). Y. Sci. Fd Agric. 25, 395.

Mauron, J. (1970). Int. Z. VitamForsch. 40, 209.

Mercier, C. (1971). Feedstuffs, Minneap. 43, Part 50, 33.

Mercier, C., Ivorec-Szylit, O., Guilbot, A. \& Calet, C. (1965). C. r. hebd. Séanc. Acad. Sci., Paris 263, 2033.

Nesheim, M. C. \& Carpenter, K. J. (1967). Br. F. Nutr. 2I, 399.

Neudoerffer, J. S. \& Smith, R. E. (1969). Can. F. Anim. Sci. 49, 205.

Nitsan, Z. \& Alumot, E. (1963). F. Nutr. 80, 299.

Njaa, L. R., Utne, F. \& Braekkan, O. R. (1966). FiskDir. Skr. Ser. Tekn. undersok. 5, 1.

Opstvedt, J. (1974). Feedstuffs, Minneap. 46, Part 23, 22.

Osborne, J. B. \& Mendel, L. B. (1917). f. biol. Chem. 32, 369.

Payne, W. L., Combs, G. F., Kifer, R. R. \& Snyder, D. G. (r968). Fedn Proc. Fedn Am. Socs exp. Biol. 27, 1199.

Payne, W. L., Kifer, R. R., Snyder, D. G. \& Combs, G. F. (1971). Poult. Sci. 50, 143.

Petersen, C. F. \& Sauter, E. A. (1968). Poult. Sci. 47, 1219.

Petersen, V. E. (1972). Cereal Processing and Digestion, p. 67. London: US Feed Grains Council.

Potter, L. M., Stutz, M. W, \& Matterson, L. D. (rg65). Poult. Sci. 44, 565.

Pritchard, P. J. (1972a). Comp. Biochem. Physiol. 43A, 195.

Pritchard, P. J. (1972b). Nutritional Physiology of Poultry, p. I. Edinburgh: East of Scotland College of Agriculture.

Rose, R. J. \& Arscott, G. H. (1962), Poult. Sci, 4I, 124.

Salter, D. N. \& Coates, M. E. (1971). Br. f. Nutr. 26, 55.

Salter, D. N., Coates, M. E. \& Hewitt, D. (1974). Br. $\mathcal{F}$. Nutr. 3I, 307.

Saunders, R. M., Conner, M. A., Edwards, R. H. \& Kohler, G. O. (1972). Cereal Chem. 49, 436.

Saunders, R. M., Walker, H. G. \& Kohler, G. O. (1969). Poult. Sci. 48, 4997.

Scott, M. L., Nesheim, M. C. \& Young, R. J. (1969). Nutrition of the Chicken. Ithaca: M. L. Scott and Associates.

Sell, J. L. \& Thompson, O. J. (1965). Br. Poult. Sci. 6, 345.

Summers, J. D., Slinger, S. J. \& Cisneros, G. (1967). Cereal Chem. 44, 318.

Thornburn, C. C. \& Willcox, J. S. $(1965 a)$. Br. Poult. Sci. 6, 23.

Thornburn, C. C. \& Willcox, J. S. (1965b). Br. Poult. Sci. 6, 33.

Vogt, H. \& Stute, K. (1971). Arch. Geflïgelk. 35, 29.

Vohra, P. (1972). Cereal Processing and Digestion, p. 53. London: US Feed Grains Council.

Vohra, P. \& Kratzer, F. H. (1964). Poult. Sci. 43, I 164.

Whitehead, C. C. \& Fisher, C. (1975). Br. Poult. Sci. (In the Press.)

Willingham, H. E., Leong, K. C., Jensen, L. S. \& McGinnis, J. (1960). Poult. Sci. 39, 103. 